\title{
'n Historiese blik op Paulus, sy werk en sy geskrifte
}

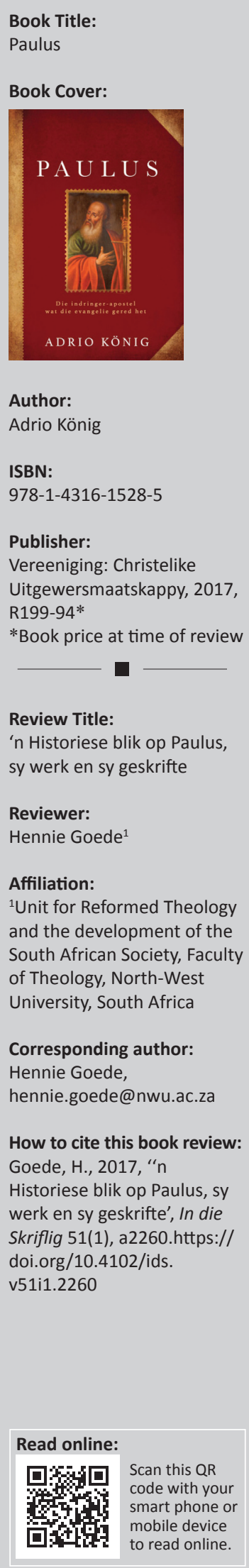

Die titel van hierdie publikasie trek onmiddellik aandag: 'Paulus'. Die impak wat hierdie apostel van Jesus Christus as Bybelskrywer en teoloog gemaak het, kan moeilik oorskat word. Daarom is publikasies oor hom en sy teologie geneig om op een of enkele aspekte van sy persoon en werk te fokus. Adrio König kyk egter met 'n wyehoeklens na Paulus soos die beskrywing op die voorblad suggereer: 'Die indringer-apostel wat die evangelie gered het'. Die outeur is bekend as 'n uitgesproke en kontroversiële teoloog en sy unieke benadering tot Paulus en sy teologie doen sy reputasie in hierdie opsig gestand.

König beskou Paulus en sy werk deur 'n historiese bril. Hy bespreek die hoofaspekte van Paulus se teologie soos dit met verloop van tyd ontwikkel. Daarom volg die bespreking nie die Paulusbriewe se kanoniese volgorde nie, maar eerder die historiese volgorde volgens datering. Die gevolg is dat die publikasie 'n unieke mengsel van besondere kanoniek, sosio-historiese konteks en dogmatiek aanbied.

In hoofstuk 1 stel König die vraag wat as die fokus van hierdie werk beskou kan word: 'Het Paulus ons van Jesus beroof?', of anders gestel: 'Het Paulus dan 'n ander evangelie verkondig as wat Jesus tydens sy aardse bediening verkondig het?' Die outeur se antwoord is dat Jesus se bediening in sy staat van vernedering geskied het, terwyl Paulus vir Jesus as die Opgestane en Verheerlikte verkondig. Hierin hoor mens weerklanke van Rudolph Bultmann se onderskeid tussen die historiese Jesus en die opgestane Christus. Tog stel König dit dat hierdie onderskeid nie deur Paulus getref is nie, maar eerder deur die verheerliking van Jesus na sy verlossingswerk afgedwing is en so 'n nuwe bedeling ingelui het waarvan Paulus die baanbreker was.

In die lig van hierdie stelling, ondersoek die skrywer vervolgens die lewe en werk van Paulus (sy preke ingesluit). Hy fokus ook op enkele temas uit die werke van die apostel wat histories (en soms dogmaties) belig word: redding deur geloof in Christus alleen, die kruis en opstanding van Christus, die doop en besnydenis, die nuwe lewe in Christus en deur die Gees, die kerk, die wederkoms en God. Die hoofstuk oor die plek van Israel in die teologie van Paulus verdien besondere vermelding, aangesien König, na my mening, daarin slaag om die saak eenvoudig te stel sonder om die ingewikkeldheid daarvan te onderspeel. Telkens raak die skrywer ook in die lig van die publikasie se fokus sake aan wat vir vandag se kerke relevant is, byvoorbeeld die rol van die vrou in die kerk, die missionale karakter van die kerk en 'n tendens onder sommige Christene om terug te keer na die seremonies en gebruike van die Ou Testament.

Die skryfstyl is gemaklik, hoewel daar heelwat herhaling voorkom. Dit blyk wel asof die laaste paar hoofstukke meer aandag verdien as wat daaraan gewy is. Die onderwerpregister is baie bondig en uitbreiding hiervan sou moontlik die publikasie ' $n$ staanplek as verwysingsgids oor Paulus kon gee. 'n Kontroversie wat die skrywer nie aanraak nie, is die Nuwe Perspektief op Paulus wat spesifiek inspeel op 'n alternatiewe interpretasie van die Jode se klem op verlossing deur goeie werke. Indien in ag geneem word dat hierdie boek enersyds 'n meer populêre publikasie is en andersyds die sentrale rol wat hierdie saak in die outeur se argument speel, sou 'n beskrywing hiervan tog relevant wees.

König slaag in sy doel met hierdie publikasie omdat sy historiese beskouing van Paulus, sy werk en sy geskrifte die ruggraat daarvan vorm. Enige historiese beskouing van ' $n$ antieke teks is tot ' $n$ mindere of meerdere mate op aanname, teorie en konstruksie gebaseer. Hieroor sou 'n mens sekerlik van die skrywer kon verskil, maar in die geheel gesien, bied hy 'n nuttige historiese raamwerk vir ons verstaan van die apostel wat na die nie-Jode gestuur is. In die slothoofstuk kom die outeur tot die gevolgtrekking dat die wetsvrye evangelie van die buitestander, Paulus, eerder as die wetsgebonde evangelie van die binnekring in Jerusalem, die evangelie vir alle mense word. So bereik God deur die verlossingswerk van sy Seun en die vernuwingswerk van sy Gees sy doel met sy evangelie, naamlik om genade en redding aan alle mense te laat verkondig. So word ons ook deel van God se begenadigdes.

Ek beveel hierdie publikasie met vrymoedigheid aan. 